\title{
Culture influence on Algerian Students' EFL Writing An Insight into Teachers' Practices
}

\begin{abstract}
:
The paper discusses a qualitative study that aims at exploring teachers' perceptions and attitudes toward the role of culture in the foreign language writing class. It is based on the hypothesis that teachers of writing at the Ecole Normale Supérieure of Constantine (ENSC) have little awareness of the role of culture in the foreign/ second language writing class, that they have little knowledge of contrastive/ intercultural rhetoric, and that their teaching instruction (methodology, feedback, evaluation) does not reflect any culture consciousness or contrastive/ intercultural rhetoric use. To verify this hypothesis, interviews were conducted with three, experienced teachers of written expression at the department of English at the ENSC. Teachers' responses have confirmed the aforementioned hypothesis.
\end{abstract}

\section{Key words:}

ESL/ EFL writing, culture, contrastive/ intercultural rhetoric, awareness.

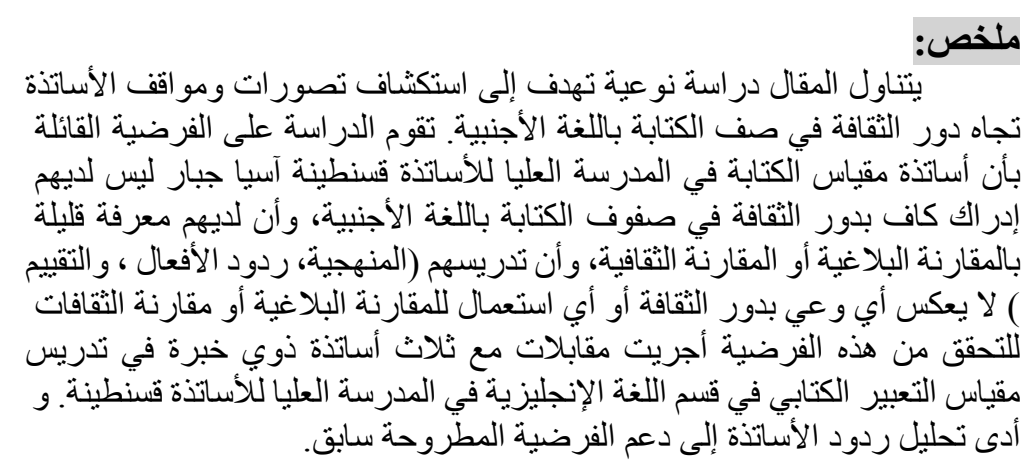

\author{
Amina Haddad \\ Département de des langues Anglaise \\ Université de Constantine03
}

\section{Introduction :}

Many English as a Second/ Foreign Language $\left(\mathrm{EFL}^{1} / \mathrm{ESL}\right)$ learners come to the writing classroom with some cultural and linguistic background that is very often significantly different from the English one. The role of the teacher in such situations is crucial, for he needs to be aware of the cultural differences existing between writing in English and writing in the students' first language (L1). In a true EFL context like the Algerian one, the teacher is supposedly more cognizant of the two cultural and writing systems and thus would easily make these differences overtly apparent to his students (Kaplan, 1966). If teachers fail to perceive the role of culture, they will tend to highlight only one facet of the intricate EFL learning context, basically the one pertaining to the English language itself or to the learner, and disregard another important side which is the L1 influence. However, it seems quite indispensible to get enough contrastive knowledge of the students' L1 and English writing systems. This can help teachers make suitable decisions about the method of instruction, feedback and evaluation procedures that best fit the students' needs. By the same token, learners' awareness of cultural and L1 influence would be raised. 
In the department of English at the Ecole Normale Supérieure Constantine (ENSC), writing is taught during the three years common core cycle. The writing course in the $1^{\text {st }}$ and $2^{\text {nd }}$ years takes up (together with the speaking one) a chief position in the curriculum with a 4hours and a half weekly time course and coefficient 3. Students are initiated into academic writing in English through developing the skills of paragraph and essay writing in $1^{\text {st }}$ and $2^{\text {nd }}$ years respectively. In the third year, those skills are further consolidated in a 3 hours per week course. Yet, students' writing skill does not evolve at the same pace as their speaking one. And upon graduation (the $4^{\text {th }}$ and $5^{\text {th }}$ year for, respectively, middle and secondary school teachers), many teachers, while correcting students' training reports or final dissertations, repeatedly complain about the insufficient quality of the writing of many students and the amount of non-nativeness and L1 writing patterns it still exhibits even at such an advanced level. Such a situation raises questions about the teaching of writing in the ENSC, and more particularly about the extent of awareness of the writing teachers about the intricacies of EFL writing such the potential role of culture.

\section{Writing in foreign Language Contexts}

In the SL/ FL context, learners often identify writing as their chief trouble. A SL/ FL student may have a good command of the grammatical system and an excellent control of the sentence structure, but they may not be able to compose good texts (Kaplan, 1988). This is particularly true because writing is a laborious skill which requires, according to Bell and Bernaby (1984), the manipulation of a lot of variables and the demonstration of many skills at the same time not only at the sentence level, such as the mastery of sentence structure, vocabulary, punctuation, spelling and letter formation, but also beyond the sentence level such as the ability "to structure and integrate information into cohesive and coherent paragraphs and texts" (as cited in Nunan 1989: p. 36). In other words, composing texts calls for several other skills (Bourouba, 2012) such as generating ideas about a given topic which requires knowledge of the world; organising these ideas along their appropriate rhetorical patterns and rhetorical conventions of written texts, which implies genre knowledge; and communicating the ideas appropriately so as to avoid misunderstanding or miscommunication which requires cross-cultural knowledge.Therefore, differences in language structures, writing 
conventions as well as cultural variables would contribute to FL/ SL making the writer's task even more complicated than his L1 writing task.

Yet the picture has not always been that clear. In the history of research into the SL/ FL writing instruction, researchers and teachers' attitudes have generally fluctuated between two main views. The first view holds that writing in L1 varies from writing in L2. Raimes (1985) revealed differences in the writing processes of skilled L2 writers and native writers. Silva (1993),in turn, analysed 72 reports of empirical research that compared L1 writing of subjects from 27 different linguistic backgrounds with L2writingandfound out that significant differences exist between L1 and L2 writing at two levels: (1)Composing processes (and sub-processes: planning, transcribing, and reviewing) and (2) Texts features (fluency, accuracy, quality, and structure, i.e., discourse, morpho-syntactic, and lexico-semantic).

The second position holds that L2 writing is similar to L1 writing. Berman (1994), for instance, asserts that writers transfer their writing strategies from their L1 to their L2 depending on their English grammatical proficiency. Likewise, Zamel's (1983) case study of six skilled and unskilled ESL writers revealed that there are similarities between the skilled L2 writers and L1 writers and that "skilled ESL writers explore and clarify ideas and attend to language-related concerns primarily after their ideas have been delineated" (p.164). Matsumoto's (1995) investigation in Japan also demonstrates that professional EFL writers use strategies similar to those used by skilled native English speakers.

The growing evidence from the FL/ SL writing research field seems to feed among researchers the conviction that there is a positive relationship between the two processes and "that literacy skills could be transferable across languages" (Zhang, 2008: p. 92). More accurately, both L1 and L2 writers grossly experience similar physical activities while pre-, during, and post- writing stages. Still, they "differ in the inner extra thinking activities that non-native writers practice to reduce the transfer of first language rules during the writing processes." (Lincoln \& Ben Idriss, 2015, p. 1) Moreover, L1 influence on the L2 writer can be positive or negative." (Darus and Ching 2009: p. 244)

\section{The Place of Culture}

According to Silva et al (1997; cited in Edlund, 2003), ESL students' cultural background influences everything from conceptions 
of audience to organizational patterns. In order to be able to sense such an influence, SL/FL writing teachers need to be aware of the cultural dimensions of writing and the key role culture plays during students' writing. But first are SL/ FL teachers expected to be adequately acquainted with this debatable concept? As a matter of fact, there is little consensus about the very meaning of culture which has been often allocated several interpretations. For Lado (1957), it is the ways of people; and for Scarino and Liddicoat (2009: p. 19), it is "a body of knowledge that people have about a particular society". For other scholars like Connor and Traversa (2014), it is the set of values, beliefs, artifacts and behavior, and communication patterns that define the lifestyle of a group of people.

Some other definitions of culture, however, seem to be of a particular significance in EFL/ESL teaching. One approach, for instance, consists in breaking the concept up into two broad categories: Big ' $C$ ' culture and little 'c' culture (Chlopek, 2008; Lee, 2009; Kramsh, 2013). The Big ' $C$ ' culture represents the easiest aspect to learn about culture, and it embodies "a set of facts and statistics relating to the arts, history, geography, business, education, festivals and customs of a target speech society" (Lee, 2009: p. 78). Such a type of culture has often constituted the content of literature, history, cultural, etc. courses in most FL/SL language curricula all over the world. Small ' $c$ ' culture, on the other hand, represents the deeper sense of culture that is not easily observable (Lee, 2009) for it encompasses a wide range of non-tangible, inter-connected features. With the exception of some of them, many of the features are hidden and "deeply internalized and subconscious" to the individual "and are often noticed only in contrast with another culture". (Chlopek, 2008: p. 11) Small 'c' culture features include "attitudes, assumptions, beliefs, perceptions, norms and values, social relationships, customs, celebrations, rituals, politeness conventions, patterns of interaction and discourse organization, the use of time in communication, and the use of physical space and body language. (Chlopek, 2008) Being more influential and determinant of people's way of thinking, linguistic/non-linguistic behaviour and expectations and interpretations of other people's linguistic/nonlinguistic behaviour (Chlopek, 2008), this type of culture is often the perfect input for the development of a communicative competence and the acquisition of conversational skills in communicative EFL teaching (Kramsh, 2013). Therefore, successful cross-cultural communication 
requires the knowledge of the small-c culture of a given community (Chlopek, 2008). However, by contrast to Big ' $\mathrm{C}$ ' culture, this type of culture is not easy to inculcate and learn in FL learning contexts. As such, to be able to accompany learners during their FL journey, teachers need to be sufficiently aware of the connotations of culture, of its significance in a language class as well as of the symbolic systems of the target language (Nissila, 1997).

\section{Contrastive/ Intercultural Rhetoric}

Attention to the basic differences between L1 and L2 writing processes and the possible role learner's culture and L1 may have on L2 writing was brought to prominence as early as the 1966 with Kaplan's landmark article "Cultural thought patterns in intercultural education" which established what became known as contrastive rhetoric (CR) as new discipline in comparative linguistics. CR is the comparative study of writing styles across different languages for the sake of identifying and explaining difficulties, and eventually facilitating writing in FL/ FL. Connor (1996: p. 5) defines it as "an area of research in second language acquisition that identifies problems in composition encountered by second language writers and, by referring to the rhetorical strategies of the first language, attempts to explain them". Recently, the term intercultural rhetoric (IR) has been introduced by Connor (2004) to replace CR although this latter is still being adopted in many studies, mostly interchangeably with CR. The need for a new name for the discipline has been provoked by the major changes in the field of contrastive rhetoric, pertaining mainly to shifts in the epistemological understanding of culture, identity, and empirical research (Oberheu, n.d.). Therefore, Connor (2011: p. 2) defines IR as "the study of written discourse between and among individuals with different cultural backgrounds. By discourse, I mean language use beyond the sentence as well as social and ideological assumptions that are associated with communication".

According to $\mathrm{CR} / \mathrm{IR}$, written texts exhibit culture-specific discourse arrangements which in fact reflect differences in thought patterns across cultures, for logic (in the popular, rather than the logician's sense of the word) upon which rhetoric is grounded, is not universal but culturally bound (Kaplan,1966). Kaplan eventually identified five different paragraph developments depicting different cultural thought patterns: English, Romance, Russian, Oriental, and 
Semitic and created a graphic representation of each- more known as the 'doodles diagram' (figure 1).

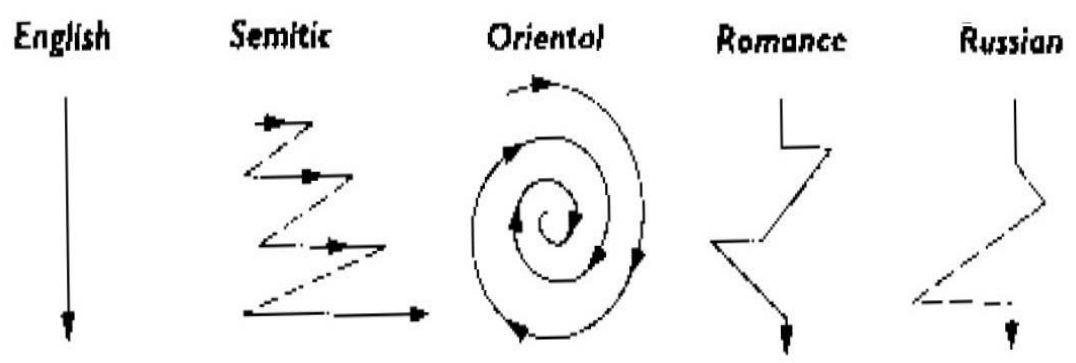

Figure1: Discourse Patterns Diagrams (Kaplan, 1966: p. 21)

The English paragraph has a linear, ordered and direct pattern of development. Latin or Romance writing (French, Spanish, Italian, Greek, and Portuguese) allows quasi-linear digressions from the main topic and value embellished symbolic and metaphoric structures. Next, Asian or oriental writing follows an indirect approach characterised by 'inconclusive' spiral progression. Slightly similar to the Latin rhetoric, Russian writing allows digression or extraneous material. Arabic (and Semitic languages), on the other hand, proceeds through "a complex series of parallel constructions, both positive and negative" (Kaplan, 1966: p. 15). That is, the Arabic rhetoric exhibits a preference for long sentences made of several almost equal clauses and a frequent use of conjunctions, especially ' $w a$ ' (and). Kaplan maintains later (in 1988) that the primary focus of writing in Arabic rests on the language of the text, not on its propositional structure.

The abundant subsequent empirical enterprises aiming at either confirming or rejecting his work, based mainly on text analysis, did nothing but help to broaden the field. CR/IR studies have been then taken onward by Connor $(1996,2004,2008,2011)$ and other advocates of the discipline such as Hinds (1983, 1987; cited in Kaplan, (1990) and Connor, 2008) Matsuda (1997) and others. Current CR has thus shifted from the original assumption that L2 writing reflected L1 thought patterns to the one pertaining that L2 displayed "preferential tendencies" of L1 language and culture (Kaplan, 1988; Allaei and Connor, 1990). Moreover, CR/IR studies have contributed to expose 
various rhetorical differences across language and participated to provide sound explanations of SL/ FL phenomena. Hinds (1987; cited in Kaplan, (1990) and Connor, 2008), for instance, has uncovered the difference between reader-responsible languages, such as Japanese, where the writer composes relying extensively on the shared worldknowledge and the writer-responsible languages, like English, in which readers expect the writer to make texts fully coherent. Soter (1988), on the other hand, examined textual elements of narration of a group of Arabic, Vietnamese and native English speakers in Australia and has demonstrated 'some degree' of influence of students' prior knowledge of literacy and literacy experiences on their L2 experience and writing performance.

$\mathrm{CR} / \mathrm{IR}$ has some undeniable pedagogical significance. It provides teachers with input into students' cross-cultural texts, and helps them identify, understand and clarify rhetorical structures. In this regard, $\mathrm{CR} / \mathrm{IR}$ has contributed to convey at least three kinds of explanations for the organizational structure of L2 texts: linguistic, cultural, and educational explanations (Matsuda, 1997). The linguistic explanation holds that the writer's L1 has a gigantic, if not determining, influence on the L2 texts structures. Similarly, the cultural explanation implies that organizational structures are strongly influenced, if not determined, by the cultural background of the writer. And according to the educational explanation, it is necessary to find out how writers acquire the patterns they use in their writing in the first place, for the structures of ESL texts will be explained in terms of educational backgrounds such as prior Ll writing instruction. Actually, CR/IR would be more beneficial for an EFL writing teacher who deals with a group of EFL students from a single native language and educational background, more especially "if the students have consciously learned contrasting text forms in their native languages." (Leki, 1991, cited in Nishi, n.d.: p. 72)

In view of what has been discussed so far, L2 writing instruction represents a realm of its own: it has unique characteristics and requirements. With the huge spread and development of technological devices such as internet, there is a plethora of English writing instruction resources (textbooks, materials, activities, etc.) at the disposal of teachers. However, these would be efficient only if teachers are aware of the special needs of their specific L2 writers. Thus, acquaintance with $\mathrm{CR}$ can be beneficial for both teachers and learners 
in an EFL context. Sharing an L1 cultural knowledge with his learners, the teacher then is in a better position to understand the difficulties students may have with writing and the origin of these difficulties. As a result, they are more likely to "teach the expectations of the English audience to L2 writers and thereby... help them increase their perceived quality of their text" (Leki, 1992: p. 92) and to "adjust their writing instruction to respond to L2 differences in writing development" (de Jong and Harper, 2005: p. 108). It is true that the growing research evidence supports the idea that "Good writing instruction is studentcentered and process-oriented without losing sight of quality writing products" (de Jong and Harper, 2005: p. 108). However, in view of what has been said above, the in-class CR/IR constructed knowledge would enable teachers to make more goal-oriented decisions on whether implementing a product, a process or a product-process oriented instruction. Furthermore, both teachers and learners would make an optimal use of writing evaluation and feedback practices.

\section{The Study}

The present study aims to explore teachers' perceptions of and attitudes towards the role of culture in the foreign language writing class. It is based on the hypotheses that writing teachers at the ENSC do not have enough awareness of the role of culture in the FL/ SL writing class, that they have little knowledge of contrastive/ intercultural rhetoric, and that their teaching instruction (methodology, feedback, evaluation) does not reflect any culture awareness or contrastive/ intercultural rhetoric use.

To verify the aforementioned hypothesis, interviews were conducted with three teachers of the written expression (WE) module in the department of English at the ENSC during the first two weeks of June 2015. The three teachers, one from each level, are the most experienced teachers of writing in the department with an experience of 8 years for $1^{\text {st }}$ and $3^{\text {rd }}$ year teachers, and 10 years for the $2^{\text {nd }}$ year one; they have also carried out the task of coordination between the teachers of their respective WE teams.

The interview is based on a loose structure or topic guide made up of 3 sections, each made mostly of open-ended questions: (1) Identification and account of learners' writing problems, (2) Approaches and attitudes towards teaching and evaluating writing in the FL class, and (3) Perceptions of the place of culture in their actual practices and knowledge and extent of use of the intercultural/ 
contrastive rhetoric in their teaching. Other themes were identified in the course of discussions with teachers. The recording of the interview data took place by means of note-taking and audio recording (using a mobile device application). The average interview took 30 minutes (with a range from 30 to 38 minutes). Then, each interview was fully transcribed for analysis and interpretation.

\section{Findings and Discussion}

The coding and analysis of teachers' responses has produced the following results displayed in the tables below. The results include responses to the interview questions and identify topics related the object of research: culture and the teaching writing practices in addition to themes not initially planned in the interview but were identified in the course of discussions with teachers.

\section{Students' Writing Problems}

\begin{tabular}{|c|c|c|c|}
\hline Level & $1^{\text {st }}$ year & $2^{\text {nd }}$ year & $3^{\text {rd }}$ year \\
\hline $\begin{array}{l}\text { Most common } \\
\text { problems }\end{array}$ & $\begin{array}{l}\text { 1) Grammatical errors } \\
\text { 2)Spelling mistakes } \\
\text { 3)Limited vocabulary } \\
\text { 4)Vocabulary transfer } \\
\text { from Arabic } \\
\text { 5) No outline use }\end{array}$ & $\begin{array}{l}\text { 1) Wordiness } \\
\text { 2) Lack of content } \\
\text { information } \\
\text { 3) Topical paragraph } \\
\text { problems (due to } \\
\text { insufficient } \$ \\
\text { instruction in } 1^{\text {st }} \text { year) } \\
\text { 4) No outline use }\end{array}$ & 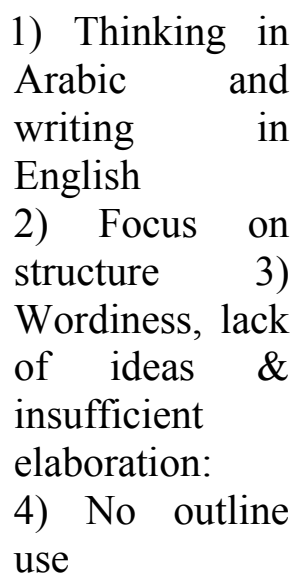 \\
\hline
\end{tabular}

Table 1: Teachers' Perceptions of Students' Writing Problems

Interviews with teachers revealed that there are some typical areas of trouble specific to each level of instruction; still, some other problems are observed in the $1^{\text {st }}$ year and persist all through the next two years. All in all, the most frequent writing problems articulated by teachers can be classified under two categories: (1) Problems related to the quality of the written product/ text, and (2) Problems related to the process of writing or the teaching writing approach.

\subsection{Problems Related to the Quality of the Written Product}


As far as this first type of problems is concerned, it is worth mentioning that some problems are quite unique to each level while others are common to the three levels among which culture- specific problems.

In the $1^{\text {st }}$ year, the most common, apparent and persistent types of writing problems students make appear at the micro linguistic level, mainly at the grammatical (eg. Errors in tenses) and lexical (limited vocabulary, and vocabulary transfer from Arabic) levels and mechanics (spelling mistakes). However, the writing problems pertaining to both $2^{\text {nd }}$ and $3^{\text {rd }}$ year levels are displayed at the macro linguistic level; that is the rhetorical organization and ideas development. Students in the $2^{\text {nd }}$ year lack content information due, according to the teacher, to lack of reading. They also exhibit problems when writing topical paragraphs such as the frequent absence of a topic sentence, the presence of many controlling ideas, and the lack of unity which the teacher attributes to insufficient paragraph instruction in $1^{\text {st }}$ year. Students' writing in the $3^{\text {rd }}$ year, on the other hand, suffers more specifically from lack of support and insufficient ideas development. "The essay discusses one idea from the beginning to the end and they just keep on repeating it" ( $3^{\text {rd }}$ year teacher).

Teachers' responses yielded some other problems that are common to two and sometimes three levels. The most common of these is wordiness which usually appears in students' writings at the three levels. In addition, students in both $2^{\text {nd }}$ and $3^{\text {rd }}$ years show lack of ideas. Besides, transfer and L1 culture influence is a recurrent problem for both $1^{\text {st }}$ year students but was not mentioned by $2^{\text {nd }}$ year teacher. However, in $1^{\text {st }}$ year transfer problems are perceived, once again, at the micro level ("Vocabulary transfer from Arabic"); in the $3^{\text {rd }}$ year they are at the macro or discourse level ("students 'think in Arabic and write in English' regardless of the appropriateness of meaning"). However, the teacher could not present concrete linguistic/ rhetorical illustrations of this type of problems. Hence, it seems that lack of information, insufficient elaboration and culture-specific problems do persist until a quite advanced level; advanced level students continue to experience some rhetorical problems at the macro-linguistic (inter-sentential, text or discourse) level.

\subsection{Problems Related to the Writing Process}

The second type of problems identified by teachers uncovers students' perceptions of the process of writing itself mainly through their attitudes toward the stages of writing development. First, students 
show a real resistance to the planning stage. Students in the three levels are reluctant to engage in any pre-writing or planning activities. Actually, most of them would engage in drafting without a pre-designed outline. Even in exams, they tend not to use them unless the teacher obliges them to do so. Apparently, this is a culturally-based issue; writing in Arabic is not characterized by the use of phases. Yet, the outline may be a very useful strategy for an EFL writer. Richard (1992; (cited in Alodwan and Ibnian, 2014) pointed out that the more time students spend on pre-writing activities, the more successful their writing will be. Al Abed (1992) further asserted that "the pre-writing stage encourages effective writing because it prompts originality, creativity, and personal awareness" (cited in Alodwan and Ibnian, 2014: p. 147). In the case students whose L1 is Arabic where writing operates according to rhetorical patterns different from English, planning and in particular outline use could prevent many of students writing problems like wordiness $\left(2^{\text {nd }}\right.$ and $3^{\text {rd }}$ year teachers) and lack of ideas and insufficient development ( $3^{\text {rd }}$ year teacher) as it "help[s them] identify gaps in the development of ideas, arguments, and sources of evidence" (Coffin et al., 2003: p. 37)

The second problem concerns students' attitude towards revising. Students astonishingly continue to exhibit a surface error focus (revising) attitude until a quite advanced level ( $3^{\text {rd }}$ year). They always focus on form (essay structure, grammar, spelling, and mechanics) and neglect content and never revise ideas though teachers in both $2^{\text {nd }}$ and $3^{\text {rd }}$ years do not stress language correctness. Using the process approach terminologies, this is editing not revising. So, technically speaking, students do not go through the revising stage- that is "looking at organization, main points, support for main ideas, examples, and connections between ideas" (Alodwan and Ibnian, 2014: p. 148). It seems that students' conception of a FL learning as primarily the mastery of the formal features of the FL continues to persist until a quite advanced level.

Students' resistance to the prewriting steps together with their form-based revising attitudes may contribute to the explanation of the persistence of some of the students' rhetorical problems with ideas development and support at a quite advanced level. In addition, those attitudes may be culture-based. Prior writing experience and instruction in Arabic is not usually process-oriented.

\section{Teaching Writing at the ENSC}


The interviews helped to uncover some specificities of the teaching of writing to EFL students at the ENSC. These are summarized in two tables: one depicts teachers' approaches and methods of teaching writing and the second groups their evaluation and feedback practices

\subsection{Teaching Methodology}

\begin{tabular}{|c|c|c|c|}
\hline & $1^{\text {st }}$ year & $2^{\text {nd }}$ year & $3^{\text {rd }}$ year \\
\hline Method & $\begin{array}{l}\text { Product-oriented } \\
\text { Culture-free }\end{array}$ & $\begin{array}{l}\text { Process-oriented } \\
\text { Culture-free }\end{array}$ & $\begin{array}{l}\text { Process- product } \\
\text { Culture-free }\end{array}$ \\
\hline $\begin{array}{l}\text { Lesson } \\
\text { Description }\end{array}$ & $\begin{array}{l}\text { Inductive theoretical } \\
\text { input } \\
\text { Model paragraph class } \\
\text { analysis } \\
\text { Practice: topic writing; } \\
\text { in class or at home; in } \\
\text { groups, or individually }\end{array}$ & $\begin{array}{l}\text { A. Deductive theoretical } \\
\text { input } \\
\text { B. A } 3 \text { phases writing } \\
\text { assignment } \\
\text { 1) Planning: (Teacher's } \\
\text { supervision, outline } \\
\text { writing) } \\
\text { 2) Drafting } \\
\text { 3) Revising in class } \\
\text { activity (self-review, } \\
\text { peer review, teacher } \\
\text { review) } \\
-2^{\text {nd }} \text { draft writing not } \\
\text { emphasized, not further } \\
\text { revised }\end{array}$ & $\begin{array}{l}\text { A. Deductive theoretical } \\
\text { reminding } \\
\text { B. A } 3 \text { phases classroom } \\
\text { writing assignment } \\
\text { 1) Planning } \\
\text { a) Individual task } \\
\text { b) A collective outline } \\
\text { 2) Drafting } \\
\text { a) A collective draft } \\
\text { b) Individual drafting } \\
\text {-Teacher collects final } \\
\text { products. }\end{array}$ \\
\hline
\end{tabular}


Table 2: Teaching Writing Methodology

\begin{tabular}{|c|c|c|c|}
\hline $\begin{array}{l}\text { Feedback } \\
\text { practices }\end{array}$ & $1^{\text {st }}$ year & $2^{\text {nd }}$ year & $3^{\text {rd }}$ year \\
\hline \multirow{2}{*}{$\begin{array}{l}\text { Feedback } \\
\text { practices }\end{array}$} & Culture-free practices & Culture-free practices & $\begin{array}{l}\text { Culture-free } \\
\text { practices }\end{array}$ \\
\hline & $\begin{array}{l}\text { Altering practices: } \\
\text { 1) Selective teacher } \\
\text { indirect written feedback } \\
\text { (using codes) } \\
\text { 2) Class correction of a } \\
\text { student' paragraph } \\
\text { 3) Sometimes use of peer } \\
\text { feedback } \\
\text { 4) Sometimes: oral } \\
\text { feedback on a student' } \\
\text { paragraph read orally: }\end{array}$ & $\begin{array}{l}\text { 1) Teacher's } \\
\text { supervision of planning } \\
\text { activities } \\
\text { 2) Peer feedback } \\
\text {-Use of checklists in } \\
\text { revision } \\
-1^{\text {st }} \text { draft revised further } \\
\text { by teacher, keeping } \\
\text { peer comments } \\
-2^{\text {nd }} \text { draft (when } \\
\text { written) not further } \\
\text { revised }\end{array}$ & $\begin{array}{l}\text { 1) Selective } \\
\text { teacher } \\
\text { indirect } \\
\text { written } \\
\text { feedback (no } \\
\text { codes) } \\
\text { 2) Class } \\
\text { conferencing } \\
\text { for a } \\
\text { selected } \\
\text { number of } \\
\text { papers } \\
\text { - Next essay } \\
\text { type: } \\
\text { feedback } \\
\text { provided to } \\
\text { other } \\
\text { students }\end{array}$ \\
\hline $\begin{array}{l}\text { Essay } \\
\text { paragraph } \\
\text { evaluation }\end{array}$ & $\begin{array}{l}\text { / Holistic evaluation, } \\
\text { With Emphasis on } \\
\text { grammatical mistakes }\end{array}$ & $\begin{array}{l}\text {-A detailed scale for } \\
\text { exams } \\
\text { - Holistic evaluation } \\
\text { for 'writing reviews' } \\
\text { focusing on content and } \\
\text { organization }\end{array}$ & $\begin{array}{l}\text {-Holistic: } \\
\text { Emphasis on } \\
\text { content more } \\
\text { than } \\
\text { language } \\
\text { and } \\
\text { structures }\end{array}$ \\
\hline
\end{tabular}

\section{Table 3: Evaluation and Feedback Procedures}

Teachers' attitudes to writing and its teaching are reflected through their method of instruction, evaluation and feedback procedures on students writing. Interviews with teachers reveal that the teaching writing methodology in $1^{\text {st }}$ year is (1) product-oriented and form-focused. The procedure is linear, much concerned with syllabus items progression and coverage. A body of theory is presented; and then, model texts are provided for students to mimic. (2) Instruction is 
culture-free based on written texts structures and rules rather than focusing on writing skills pertaining to students' special needs as EFL learners with an L1 linguistic background different from English (For instance, talking about the class size, the $1{ }^{\text {st }}$ year teacher declared: "The number is appropriate ... But if your objective is to work with all the learners, the number is too-you can't"). (3) The teaching methodology does not allow for much individual writing practice since students write sometimes individually and sometimes in groups. The teacher's focus is on the texts which students produce and (4) language forms and accuracy are of primary concern. Similarly, (5) altering feedback procedures (teacher indirect feedback and peer feedback) and adopting selective ones (teacher indirect feedback on a selected number of papers and oral feedback on some papers read orally) does not permit sufficient regular individual feedback nor does it highlight culture and L1 linguistic potential influence. And to end, such feedback may not be of immediate assistance for students since the latter are (6) not systematically urged and guided to revise, nor are they encouraged to rewrite. So the method would rather be described as culture-free, product-oriented, and form-focused meant as teaching-for-testing.

On the other hand, teachers in both $2^{\text {nd }}$ and $3^{\text {rd }}$ years advocate a more process-inspired, but personalized methodology integrating text analysis. Such a methodology is characterized by (1) a special emphasis on the planning phase and (2) systematic procedures for the revising one although teachers have not exhibited techniques to orient learners towards a global/ content revision as first step before local/ form revision. The teaching procedures are (3) more interactive and learner-centered where students frequently engage in different individual writing tasks but have the chance to interact with the teacher and classmates on those tasks all along the process (planning, peerediting, class conferencing). Adopting a more 'communicative approach' to errors correction, teachers place (4) a special accent on content and ideas revising procedure using checklists. However, no rigorous pedagogical measures are employed (namely in $3^{\text {rd }}$ year) to monitor the application of this step. Probably students' persistent formoriented attitude is the proof although there is (5) no expressed focus on language correctness. (6) Yet, the methodology gives less weight to rewriting or multi-drafting.(7) Finally, none of the teachers showed a culture sensitive instruction, neither at the level of lesson design nor procedure, evaluation or feedback. Hence, the Cultural impact may be 
visible on teachers' methodology who follow their own special process-oriented instruction characterized, for instance by absence of the redrafting phase. As a matter of fact, in "Arab countries, it is not common for teachers to require more than one draft, or work on revision techniques", (Halimah, 1991; cited in Al Hamzi and Scholfield 2002: p. 238).

\subsection{The Writing Course}

\begin{tabular}{|c|c|c|c|}
\hline & $1^{\text {st }}$ year & $2^{\text {nd }}$ year & $3^{\text {rd }}$ year \\
\hline Course & Appropriate & Appropriat & Appr \\
\hline objectives & Detailedsyll & $\mathrm{e}$ & opriate \\
\hline Writing & abus with 2 & Appropriat & - 'The \\
\hline syllabus & unbalanced chapter & e & $\begin{array}{l}\text { content } \\
\text { needs some } \\
\text { revisions' }\end{array}$ \\
\hline Course Time & $\begin{array}{l}\text { - Insufficient } \\
\text { time for the } \\
\text { paragraph writing } \\
\text { chapter }\end{array}$ & $\begin{array}{l}\text { - Time: } \\
\text { enough, but not } \\
\text { for the PA }\end{array}$ & $\begin{array}{l}\text { Insuf } \\
\text { ficient time } \\
\text { for practice }\end{array}$ \\
\hline
\end{tabular}

\section{Table 4: Teachers' Views of the Writing Course}

One of the themes that were identified during the interviews concerns teachers' views of the about the writing course. The three of them seem to agree on two things: the appropriateness of course objectives and the need for more time for writing practice. However, they have dissimilar views regarding the writing syllabus content of the course. While the $2^{\text {nd }}$ year teacher finds it just appropriate, the $3^{\text {rd }}$ year one thinks some revision is necessary. Yet, this latter concerns only the re-ordering of some of the content's elements. On the other hand, the $1^{\text {st }}$ year syllabus is a subject of complaint for not only the $1^{\text {st }}$ year teacher but the $2^{\text {nd }}$ year one as well.

The $1^{\text {st }}$ year's writing syllabus' is sentence-centered, and its content is structured unevenly. Characterized by an over focus on sentence structures, the $1^{\text {st }}$ year writing syllabus allots insufficient instruction for paragraph writing. The $1^{\text {st }}$ chapter of the syllabus, which spreads throughout the first and longest term, is largely devoted to teaching types of constructions (phrases, clauses and types of sentences). These are also part of the grammar syllabus. So teaching them again in the writing course not only creates redundancies but also reduces the amount of time that ought to be assigned to the teaching of 
constructions beyond the sentence level, namely the paragraph which is left with the shortest last terms. The result of such a shortcoming is immediately perceived in the writings of the $2^{\text {nd }}$ year students. In this year, though they first go through a brief paragraph writing review, students engage directly in essay writing. While they show little problems with the new items- essay organization and structure, they continue to have troubles writing good topical paragraphs, ending often with paragraphs without topic sentences, with many controlling ideas and with no unity. Such a situation creates an extra burden to the $2^{\text {nd }}$ year writing teacher who would teach the $2^{\text {nd }}$ year syllabus while handling problems related to the $1^{\text {st }}$ year syllabus which may not have been adequately assimilated.

3. Culture in the Writing Class

3.1. Teachers' Perceptions of and Attitudes towards the Role of FL Culture in the FL Writing Class

\begin{tabular}{|c|c|c|c|}
\hline & $1^{\text {st }}$ year & $2^{\text {nd }}$ year & $3^{\text {rd }}$ year \\
\hline \multirow{3}{*}{$\begin{array}{l}F L \\
\text { Culture }\end{array}$} & $\begin{array}{l}\text { A culture-free } \\
\text { instruction }\end{array}$ & $\begin{array}{l}\text { A culture-free } \\
\text { instruction }\end{array}$ & $\begin{array}{l}\text { A culture-free } \\
\text { instruction }\end{array}$ \\
\hline & $\begin{array}{l}\text { Awareness of the } \\
\text { importance of FL } \\
\text { culture knowledge } \\
\text { (Big 'C' attitude) }\end{array}$ & $\begin{array}{l}\text { - Awareness of the } \\
\text { importance of FL } \\
\text { culture knowledge } \\
\text { (Big 'C' attitude) } \\
\text {-Cultural knowledge to } \\
\text { be developed through } \\
\text { reading }\end{array}$ & $\begin{array}{l}\text { Unawar } \\
\text { eness of } \\
\text { the } \\
\text { importa } \\
\text { nce of } \\
\text { the FL } \\
\text { culture } \\
\text { knowled } \\
\text { ge }\end{array}$ \\
\hline & $\begin{array}{l}\text { 'sometimes' dealt with } \\
\text { through writing } \\
\text { samples analysis }\end{array}$ & $\begin{array}{l}\text { 'maybe' considered } \\
\text { during the model essays } \\
\text { selection }\end{array}$ & $\begin{array}{l}\text { 'maybe' } \\
\text { unconsc } \\
\text { iously } \\
\text { consider } \\
\text { ed } \\
\text { during } \\
\text { model } \\
\text { essays } \\
\text { analysis }\end{array}$ \\
\hline
\end{tabular}

Table 5: Teachers' Perception of the Fl Culture in the Writing Class 
As far as the place of FL culture in the writing class is concerned, teachers' responses reveal three significant results: (1) Teachers' attitudes vary from little awareness (the case of the two $1^{\text {st }}$ and $2^{\text {nd }}$ years teachers) to an entire unconsciousness of the matter as is the case of the $3^{\text {rd }}$ year teacher who declared "Frankly speaking, I've never thought about this before". (2) The little amount of awareness, when existing, is reflected through a kind of 'theoretical' knowledge of the importance of the target language culture information in the EFL class in general, and the EFL writing class in particular. (3) The teachers have a perception of culture that is often referred to as Big ' $\mathrm{C}$ ' culture. That is culture is viewed as "a set of facts and statistics relating to the arts, history, geography, business, education, festivals and customs of a target speech society'. (Lee, 2009: p. 78) It is the tangible, observable and easily perceived aspect of culture. Their responses demonstrate a limited knowledge of the Small 'c' culture which consists of 'attitudes, assumptions, beliefs, perceptions, norms and values, social relationships, customs, celebrations, rituals, politeness conventions, patterns of interaction and discourse organization, the use of time in communication, and the use of physical space and body language. (Chlopek, 2008: p. 11). This second type of culture is less observable but more influential on people's behaviours and linguistic communication in speaking and writing. It is this attitude towards culture that is probably most required from a writing teacher. (4) The teaching writing methodology reflects a culture-free approach to writing. Culture is never considered at the preliminary lessons' stages such as objectives specification. It is mentioned only sometimes at the level of model text analysis. In this case, teachers focus on the big ' $\mathrm{C}$ ' culture and never on the cultural patterns of writing. Thus, writing in English is taught to a group of EFL Algerian students but with no concrete pedagogical considerations of the cultural dimension of the writing process in the two languages 


\subsection{Teachers' Perceptions of the Role of the L1 Culture in the} FL Writing Class

\begin{tabular}{|c|c|c|c|}
\hline & $1^{\text {st }}$ year & $2^{\text {nd }}$ year & $3^{\text {rd }}$ year \\
\hline $\begin{array}{l}\text { Perception of the } \\
\text { role of L1 culture } \\
\quad \text { on writing }\end{array}$ & Negative influence & & $\begin{array}{l}\text { Negative } \\
\text { influence }\end{array}$ \\
\hline $\begin{array}{c}\text { Culture-specific } \\
\text { problems } \\
\text { Identification }\end{array}$ & In the evaluation stage & $\begin{array}{l}\text { In essay revising/ and } \\
\text { evaluation stage }\end{array}$ & $\begin{array}{l}\text { In the } \\
\text { evaluation } \\
\text { stage }\end{array}$ \\
\hline $\begin{array}{c}\text { Type of cultural } \\
\text { influence } \\
\text { problems }\end{array}$ & $\begin{array}{l}\text { 1) Word choice more } \\
\text { than structures } \\
\text { 2) Influence on ideas, } \\
\text { logic and analysis. } \\
\text { 'Students use L1 world } \\
\text { view'. } \\
\text { 3) Wordiness }\end{array}$ & $\begin{array}{l}\text { 1) Arabic structures } \\
\text { 2) Exemplifying } \\
\text { 3) Wordiness }\end{array}$ & $\begin{array}{l}\text { 1) Students } \\
\text { "think in } \\
\text { Arabic \& } \\
\text { write in } \\
\text { English" } \\
\text { 2)Words } \\
\text { integral } \\
\text { translation } \\
\text { 3) Arabic } \\
\text { structures and } \\
\text { ideas } \\
\text { 4) Long } \\
\text { introductions } \\
\text { 5) Wordiness } \\
\text { and essay } \\
\text { poor } \\
\text { development }\end{array}$ \\
\hline $\begin{array}{c}\text { Feedback on L1 } \\
\text { (Arabic) transfer } \\
\text { errors }\end{array}$ & & $\begin{array}{l}\text {-Sometimes } \\
\text { highlighting transfer } \\
\text { errors, the revising } \\
\text { stage } \\
\text { - No cross-cultural } \\
\text { debates on the errors }\end{array}$ & $\begin{array}{l}\text { - Asking } \\
\text { students to } \\
\text { read in } \\
\text { English }\end{array}$ \\
\hline
\end{tabular}

Table 6: Teachers' Perception of the L1 Culture Influence in the Writing Class 
Regarding L1 culture influence on EFL writing, there is a consensus among writing teachers that L1 culture plays a more negative role and is much more a source of interference. However, teachers are well capable to perceive the cultural dimension of writing problems mainly at the sentence level: the lexical and syntactical level. For instance, both the $1^{\text {st }}$ and 3 rd year teachers mentioned lexical transfer from Arabic. The $2^{\text {nd }}$ year teacher, on the other hand, talked about syntactic transfer only ("But here at writing the first word in the introduction, when I read the $1^{\text {st }}$ word in the introduction, I'm reading in Arabic not English. For example, 'in the recent times' (wa mina el 3osur el hadithawa 13asr lhadith: و من العصور الحديثة العصر الحديث)( But inferred from teachers' responses, students' writings continue to comprise culture related problems beyond the sentence level too. Their writings exhibit difficulties at the macro-linguistic level with ideas organization, development and rhetorical patterns until an advanced level. Yet, teachers could not state enough tangible linguistic and rhetorical examples of those problems whose existence they themselves acknowledged,. The only concrete illustrations were wordiness which all teachers agreed on as a 'cultural' problem, 'exemplifying' ( $2^{\text {nd }}$ year) where students employ examples from L1 to back up their ideas or arguments and long introductions ( $3^{\text {rd }}$ year). Otherwise, they contented themselves by mentioning overall observations about students writing (table 5). Actually, the $1^{\text {st }}$ year teacher mentioned that her students' depend on "their L1 world view" to develop their paragraphs; but when she was asked to mention concrete linguistic examples of this influence, she simply said: "I don't know". Similarly, the $3^{\text {rd }}$ year teacher repeated more than once: "the most common difficulty I've encountered with my learners is that they think in Arabic and write in English", but she did not in fact provide any concrete linguistic and rhetorical illustrations.

Moreover, there are no systematic procedures to deal with culture influence and L1 writing problems. L1 culture problems and transfer errors are identified at the revising and/ or evaluation stages. They are cited orally, almost superficially but are never taken into consideration in subsequent lessons as potential leaning needs. There are no remedial activities to minimise L1 writing problems nor are there any planned pedagogical actions to raise learners' awareness towards the differences in writing patterns across cultures and their potential influence. The only practice teachers adopt in this regard is asking learners to read in English. 


\begin{tabular}{llll}
$\begin{array}{l}\text { 3.3. Teachers' Use of Inter-Cultural/ Contrastive } \\
\text { Rhetoric }\end{array}$ & \multicolumn{1}{l}{} \\
& $1^{\text {st }}$ year & $2^{\text {nd }}$ year & $3^{\text {rd }}$ year \\
\hline $\begin{array}{l}\text { Contrastive /Inter- } \\
\text { Itural (CR /IR) rhetoric }\end{array}$ & No use of CR/IR & No use of CR/IR & - No use of \\
& & & $C R / I R$ \\
\hline
\end{tabular}

\section{Table 7: Teachers' Use of CR/IR in the Writing Class}

Finally, teachers do not make use of intercultural/ contrastive rhetoric in the writing class at any of their lesson's phases: design and plan, teaching methodology, feedback and/ or evaluation. Owing to their little acquaintance with the role of culture in EFL writing (table 4), these teachers seem content with their 'traditional' way of teaching and do not strive to explore further the culture and L1 transfer problems that are repeatedly exhibited in their writing classes over years.

\section{Conclusion and Recommendations}

In conclusion, EFL Students' writing in general exhibits to varying levels some culture-specific patterns; and Algerian students' writing is no exception. The sample of teachers of writing to EFL students at the ENSC under study declared that their students' writing suffered from such influence too. However, their accounts of their respective instructional procedures have showed that teachers reserve no special attention to this type of problem. Thus, those teachers do not seem to exhibit a true awareness of the role of the interwoven connection between writing and culture nor are they sufficiently conscious of the place of the latter in the writing class. They embrace a culture-free approach reflected through their different teaching practices (methodology, feedback, evaluation, error attitudes, ... ). The result of such practices might just be the persistence of those culturespecific problems in students' writings until a quite advanced. However, by overlooking the influence of the L1, teachers may interpret these differences as deficits in L2 writing or even thinking ability rather than normal L2 developmental patterns; thus, teachers need to understand these linguistic and cultural contexts of writing development. ( de Jong and Harper, 2005) Nonetheless, in addition to the place of culture in the actual teaching of writing to EFL students in the ENSC, some further educational aspects have to be re-visited. So, in light of the above mentioned results, some suggestions to improve the teaching of writing in the ENSC are enlisted below 


\section{- Teachers' Cultural Training and Self-Education}

As it is the case with most EFL contexts, the Algerian EFL teaching situation is a unique one. Thus, teachers of writing should not overlook the special cultural context of their instruction and lose sight of the cultural dimension in their lesson design and plans. This can be done only if teachers are sufficiently aware of such dimensions. Consequently, it is preferable that some cultural training (seminars, study days, ...) is presented to writing teachers to widen knowledge about such notions as contrastive rhetoric, intercultural rhetoric, etc. Teachers are also advised to engage in any sort of cultural selfeducation to become well acquainted with the FL/SL writing intricacies and the thorny role of culture in the writing class. Such knowledge will do no harm but help them improve their writing methodologies and their reflective practices. As teachers, "if we take our profession seriously we should stay current with the research ...to avoid 'uncritically' applying principles”. (Colombo, 2012: p. 4)

\section{- The Writing Course Revision}

The $1^{\text {st }}$ year writing course requires a real and pressing revision. The syllabus components must be modified in such a way as to afford more space for paragraph instruction, and more importantly paragraph writing and practice. In this way, the syllabus would have a more text or discourse level focus rather than sentence focus. This can be achieved through a more coordinating work between teachers of grammar and those of $\mathrm{WE}$ in the $1^{\text {st }}$ year in order eliminate redundancies across the two courses and detach the present 'writing syllabus' aspects that can be covered in the grammar course only. This will help to reduce the first chapter's content (overloaded with grammatical points) to allow for more time and space for the second chapter- paragraph writing. At the same time, a more contextualised teaching of grammar will be possible in the writing course: teaching language forms (sentence structures, vocabulary and grammar) indirectly, as a secondary objective while practicing paragraph writing skills (paragraph structure, organization and development).

\section{- The WE Team Role}

The department of English at the ENSC includes teaching teams for most of the courses, but it is readily observable that those teams are not effectively working; the WE team is a case in point. The role of this team needs to be well defined, and its work needs to be goal-oriented 
and planned. The present role of the WE team (inferred from teachers' discussions) is limited to checking syllabus items coverage and designing unified exam questions. However, this seems neither sufficient nor appropriate. The teams need to engage in regular consultation and reflective sessions, per level and across levels to initiate discussions, as necessary, about the content of the syllabus itself and the teaching methodology so as to embrace a more culture-based instruction, implement more learner-centered procedures, increase individual writing practice, provide more individualised feedback and adopt a more balanced form-content teaching, feedback and evaluation approaches.

\section{References}

Al Hamzi, S. H. \& Scholfield, P. (2007) Enforced Revision with Checklist and Peer Feedback in EFL Writing: The Example of Saudi University Students, in Scientific Journal of King Faisal University (Humanities and Management Sciences) Vol.8 No.2 1428H (2007), pp. 237- 267.

Allaei, S. K. \& Connor, U. (1990) Exploring the Dynamics of Cross-Cultural Collaboration in Writing Classrooms, The Writing Instructor, fall 1990, pp. $19-28$

Alodwan, T. A. \& Ibnian, S. S. K. (2014) The Effect of Using the Process Approach to Writing on Developing University Students' Essay Writing Skills in EFL, in Review of Arts and Humanities, June 2014, Vol. 3, No. 2, pp. 139-155.

Berman, R. (1994) Learners' Transfer of Writing Skills Between Languages, TESL Canada Journal/ Revue, Vol. 12, No.1, Winter 1994, pp. 29- 46

Bourouba, N. (2012) Teaching Writing Right: Scaffolding Writing for EFL/ESL Students Case Study: Algerian EFL Secondary School Students Challenges and Opportunities, Unpublished Master dissertation, Graduate Institute for International Training, World Learning, Brattleboro, Vermont, USA

Chlopek, Z. (2008) The Intercultural Approach to EFL Teaching and Learning, English Teaching Forum, N. 4, pp. 10- 19

Colombo, L. (2012) English Language Teacher Education and Contrastive Rhetoric, ELTED, vol.15, Winter 2012, pp. 1- 6

Connor, U. (1996) Contrastive Rhetoric: Cross-Cultural Aspects of Second Language writing. New York: Cambridge University Press - (2004) Intercultural Rhetoric Research: Beyond Texts, Journal of English for Academic Purposes 3 (2004), pp.291-304 (2008) Mapping Multidimensional Aspects of Research:

Reaching to Intercultural Rhetoric, in U. Connor, E. Nagelhout, \& W. 
Rozycki, (Eds.), Contrastive Rhetoric: Reaching to Intercultural Rhetoric, Benjamins Press, pp. 299- 315

U. (2011) Introduction, Connor, U. Intercultural Rhetoric in the Writing Classroom, the University of Michigan Press ELT. Pp. 1-10. Retrieved from: http://www.press.umich.edu/titleDetailDesc.do? $\mathrm{id}=3488851$

Connor, U., \& Traversa, A. (2014). The Role of Intercultural Rhetoric in ESP Education. Paper presented at the CELC 2014 Symposium on Culture, Cross-Cultural Communication, Intercultural Communication.

Darus, S \& Ching, K. H (2009) Common Errors in Written English Essays of Form One Chinese Students: A Case Study, in European Journal of Social Sciences - Volume 10, Number 2 (pp. 242-253)

de Jong, E. J. \& Harper, C. A. (2005) Preparing Mainstream Teachers for English-Language Learners: Is Being a Good Teacher Good Enough?, Teacher Education Quarterly, Spring 2005, pp. 101- 123

Edlund, J (2003) Non-Native Speakers of English, in I. Clark (ed.) Concepts in Composition: Theory and Practice in the Teaching of Writing. London and Mahwan, NJ: Lawrence Elbaum Associates, Publishers, pp. 363-387

Kaplan, R. B. (1966) Cultural Thought Patterns in Intercultural Education, in Language Learning 16 (1-2), Blackwell Publishers, pp. 11- 25

----- (1988) Contrastive Rhetoric and Second Language Learning: Notes towards a Theory of Contrastive Rhetoric, in A. C. Purves (Ed.), Written Communication Annual (Vol.2) Writing across Languages and Cultures. Newbury Park, CA: Sage Publications. pp. 275-304

-------- (1990.) Writing Styles of Second Language Learners. Deseret Language and Linguistic Society Symposium, vol. 16 Iss. 1, pp. $2-23$

Kramsh (2013) Culture in Foreign Language Teaching, Iranian Journal of Language Teaching Research, 1(1), (Jan., 2013), pp. 57-78

Lee (2009) Treating Culture: What 11 High School EFL Conversation Textbooks in South Korea Do, English Teaching: Practice and Critique May, 2009, Volume 8, Number 1, pp. 76- 96

Leki, I. (1992) Understanding ESL Writers. A Guide for Teachers. Portsmouth, NH: Boyton/Cook Publishers.

Lincoln, F. \& Ben Idriss, A. (2015) Teaching The Writing Process As A First And Second Language Revisited: Are They The Same?, Journal of International Education Research - Second Quarter 2015, Volume 11, Number 2, pp. 119- 124

Matsuda, P. K. (1997) Contrastive Rhetoric in Context: A Dynamic Model of L2 Writing, Journal of Second Language Writing, 6 (1 ), pp. 45-60 
Matsumoto, K. (1995) Research Paper Writing Strategies of Professional Japanese EFL Writers, TESL Canada Journal Revue TESL du Canada, Vol. 13, No.1, Winter 1995, pp. 17- 26

Nishi, K (n.d.) Contrastive Rhetoric and its Recent Studies: Implications for the Current Teaching of English Writing at Universities in Japan. Retrieved from: http://www.kyoto-seika.ac.jp/researchlab/wp/wpcontent/uploads/kiyo/pdf-data/no30/nishi.pdf

Nissila, S.P. (1997) Raising Cultural Awareness among Foreign Language Teacher Trainees, in Byram, M and G. Zarate (eds) The Sociocultural and Intercultural Dimension of Language Learning and Teaching, Council for Cultural Co-operation, pp. 55-72

Nunan, D. \& Choi, J. (2010) Language, Culture, and Identity. Framing the Issue, in C. Kramsh (ed.) Language and Culture. Reflective Narratives and the Emergence of Identity, Routledge, pp. 1-13

Nunan, D. (1989) Designing Tasks for the Communicative Classroom, Cambridge University Press

Oberheu, N. (n.d.) From Contrastive to Intercultural Rhetoric: Why Studying Intercultural Rhetoric is Important for MA TESL/TEFL Students. Retrieved from: https://nicholeoberheu.com/wpcontent/uploads/2012/05/From-Contrastive-to-Intercultural-RhetoricWhy-Studying-Intercultural-Rhetoric-is-Important-for-MA-TESLTEFL-Students1.pdf

Raimes, A. (1985) An Investigation of How ESL Students Write, Paper presented at the Annual Meeting of the Teachers of English to Speakers of Other Languages (19th, New York, NY, April 9-14, pp. 1-29

Scarino, A. \& Liddicoat, A. J. (2009) Teaching and Learning Languages. A Guide, Australian Government, Department of Education, Employment and Workplace Relations

Silva, T. (1993) Toward an Understanding of the Distinct Nature of L2 Writing: The ESL Research and Its Implications, TESOL Quarterly, Vol. 27, No. 4. (Winter, 1993), pp. 657-677.

Soter, A. O. (1988) The Second Language Learner and Cultural Transfer in Narration. In A.C. Purves (Ed.), Written Communication Annual (Vol.2), Writing Across Cultures (pp.177-205). Newbury Park, CA: Sage Publications.

Zamel, V. (1983) The Composing Processes of Advanced ESL Students: Six Case Studies, TESOL Quarterly, Vol. 17, No. 2. (Jun., 1983), pp. 165187.

Zhang, J. (2008) A Comprehensive Review of Studies on Second Language Writing, HKBU Papers in Applied Language Studies Vol. 12, 2008, pp. 89- 122

Appendix: Written Expression Teachers' Interview Guide 
Objective of the interview

The present interview is part of a research work that investigates the kinds and sources of writing problems encountered by Algerian learners of English and possibly the role of culture and mother tongue interference with such problems.

As teachers of writing, your contribution is of a precious importance. There is no right or wrong answer to the questions below. Your honesty and thoughtfulness in answering these questions is greatly appreciated and will directly benefit the research process

Thank you for your collaboration and patience.

I. Students' Writing difficulties

- During your teaching experience, what type of writing problems students' writings exhibit every year?

- What do you think the sources of these problems are

II. Teaching writing practices and attitudes

- What approach do you follow? Describe a typical lesson/ procedure/ method you follow to teach writing

- Describe the evaluation and feedback practices you adopt for writing

III. Culture and Intercultural rhetoric

1. Teachers' views of culture:

- What is the role culture in a FL language class? In a FL writing class?

- What is your approach to culture (FL and L1) while teaching writing?

- Do you integrate culture (FL and L1) while teaching writing? How?

2. Contrastive rhetoric questions:

- What is the role of L1 on writing?

- What kind of transfer mistakes do learners usually make in writing?

- What are the rhetorical characteristics of writing in Arabic that influence students writing in English?

- How do you deal with this phenomenon in your course?

- Do you use CR? 